\title{
Niektóre prawnokarne (represyjne) metody przeciwdziałania alkoholizmowi i narkotykom, w tym zwłaszcza tak zwanym dopalaczom, przez gminy
}

\author{
PIOTR JóŹWIAK \\ ORCID: 0000-0001-6223-971X \\ Katedra Prawa Publicznego i Teorii Prawa \\ Wydział Psychologii i Prawa \\ SWPS Uniwersytetu Humanistycznospołecznego w Poznaniu
}

\section{Wprowadzenie}

Problematyka roli i znaczenia samorządu terytorialnego w procesie ochrony zdrowia psychicznego jest niewątpliwie niezwykle doniosłym zagadnieniem, które zwłaszcza w ostatnim czasie stało się przedmiotem większego zainteresowania doktryny prawa. Niewątpliwie inny jest zakres zadań nałożonych w tym względzie przez ustawodawcę na województwo, a inny na powiat lub gminę.

Już na wstępie niniejszego opracowania wyjaśnienia wymaga jego tytuł. Zasadniczo metody prawnokarne są bowiem raczej zastrzeżone dla innych niż jednostki samorządu terytorialnego organów administracji publicznej, w tym zwłaszcza dla organów państwowych. Niemniej w doktrynie coraz częściej podkreśla się rolę przepisów o charakterze represyjnym (prawnokarnym) również w prawie administracyjnym, także 
w prawie samorządowym ${ }^{1}$. Samo pojęcie ,prawnokarne metody” kojarzy się zwłaszcza z prawem karnym, a przede wszystkim odpowiedzialnością karną przewidzianą za przestępstwa lub przestępstwa skarbowe

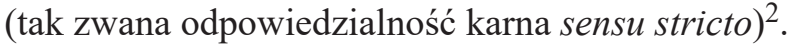

Dość powszechnie przyjmuje się jednak, że „karny” charakter mogą mieć także sankcje przewidziane w prawie wykroczeń, prawie dyscyplinarnym, a także przy egzekwowaniu odpowiedzialności wobec nieletnich i podmiotów zbiorowych (tak zwana odpowiedzialność karna sensu largo $)^{3}$. Podkreśla się również prawnokarny — przynajmniej w jakimś zakresie — charakter niektórych sankcji administracyjnych, zwłaszcza kar pieniężnych, które często zalicza się do tak zwanego administracyjnego prawa karania 4 .

W niniejszym opracowaniu wskazane zostaną te środki, które przysługują gminom w zakresie zwalczania dwóch niezwykle niebezpiecznych zjawisk, jakimi są alkoholizm i narkomania. Przeciwdziałanie obu tym zjawiskom zostało zaliczone przez ustawodawcę do zadań własnych gminy. Spośród wszystkich jednostek samorządu terytorialnego to właśnie gminy mają najszersze uprawnienia, jeśli chodzi o stosowanie

${ }^{1}$ Por. np. D. Szumiło-Kulczycka, Prawo administracyjno-karne, Kraków 2004, passim; L. Staniszewska, Administracyjne kary pieniężne. Studium z zakresu prawa administracyjnego i procesowego, Poznań 2017, s. 172-178; A.J. Szwarc, Niektóre aspekty represyjności prawa samorzadowego, [w:] Represyjność prawa samorząowego, red. A.J. Szwarc, T. Gardocka, Poznań 2015, s. 11-23; P. Jóźwiak, Represyjne kompetencje wójta (burmistrza, prezydenta) wświetle zasady in dubio pro cive, [w:] Represyjność prawa..., s. $87-102$.

${ }^{2}$ Ustawa z dnia 6 czerwca 1997 roku — Kodeks karny (tekst jedn. Dz.U. z 2019 r. poz. 1950 z późn. zm.), dalej: k.k.; ustawa z dnia 10 września 1999 roku — Kodeks karny skarbowy (tekst jedn. Dz.U. z 2020 r. poz. 19), dalej: k.k.s.

${ }^{3}$ Trybunał Konstytucyjny wielokrotnie zwracał uwagę w swym orzecznictwie, że kary i środki przewidziane w kodeksie karnym, względnie kodeksie karnym skarbowym, są tylko jednymi z wielu środków o charakterze represyjnym, podkreślając przy tym, że konstytucyjne pojęcie „odpowiedzialności karnej” jest o wiele szersze od tego przewidzianego w kodeksach karnych. Por. np. wyrok TK z dnia 4 lipca 2002 roku, P 12/01, OTK ZU 2003, nr 4 A, poz. 50, s. 731; wyrok TK z dnia 26 listopada 2003 roku, SK 22/02, OTK ZU 2003, nr 9 A, poz. 97.

${ }^{4}$ Por. A. Zoll, W. Wróbel, Polskie prawo karne. Czesść ogólna, Kraków 2010, s. $27-$ 32; M. Królikowski, R. Zawłocki, Prawo karne, Warszawa 2015, s. 27-39. 
w tym zakresie sankcji, które pełnią — choć w różnym stopniu — funkcję represyjną.

Interesujące wydaje się zagadnienie, czy realizacja tego rodzaju zadań własnych gminy może — a w dalszej kolejności, czy w ogóle powinna - się odbywać z wykorzystaniem środków o charakterze prawnokarnym. W niniejszym opracowaniu zostaną jedynie zasygnalizowane niektóre problemy, których jednoznaczne rozstrzygnięcie wydaje się konieczne i wymaga zdecydowanie bardziej pogłębionych rozważań. Doniosłość opisywanej problematyki potęguje to, że w ostatnim czasie, jak słusznie podkreśla się w doktrynie, mamy niewątpliwie do czynienia z ekspansją represyjnej funkcji administracji publicznej, do której, co oczywiste, zalicza się również administrację samorządową ${ }^{5}$.

\section{Przeciwdziałanie alkoholizmowi}

Nikt nie kwestionuje, że alkoholizm jest jednym z najpowszechniejszych i najbardziej niebezpiecznych zjawisk dla zdrowia psychicznego ${ }^{6}$. Jak słusznie wskazuje M. Koszowski:

Właściwości napojów alkoholowych jako produktów niebezpiecznych dla zdrowia, wywierających w następstwie ich spożywania w nadmiarze destrukcyjny wpływ na życie jednostek i zbiorowości, są powszechnie znane. Zagadnienie to ma, także w Polsce, przebogatą literaturę, szczegółowo omawiającą wpływ alkoholu zarówno na jednostkę (człowieka), jaki i jej otoczenie ${ }^{7}$.

Jeśli chodzi o rolę samorządu terytorialnego w zakresie przeciwdziałania temu zjawisku, to niewątpliwie jest ona znaczna. W szczególności w grę wchodzą przepisy dotyczące wydania albo cofnięcia zezwolenia na sprzedaż napojów alkoholowych (tak zwana koncesja) ${ }^{8}$, uprawnienia do

5 Por. M. Kasiński, Ekspansja represyjnej funkcji administracji publicznej jako zagrożenie demokratycznego państwa prawnego, „Roczniki Nauk Prawnych” 21, 2011, nr 1, s. 277 n.

${ }^{6}$ Ustawa z dnia z dnia 26 października 1982 roku o wychowaniu w trzeźwości i przeciwdziałaniu alkoholizmowi (tekst jedn. Dz.U. z 2019 r. poz. 2277 z późn. zm.), dalej: u.w.t.p.a.

7 Por. M. Koszowski, Przeciwdziałanie uzależnieniom. Regulacje prawne, Warszawa 2019, s. 129.

8 Ibidem, s. 163. 
wprowadzenia zakazu sprzedaży, podawania i spożywania napojów alkoholowych, a zwłaszcza zasady ustalania warunków dotyczących licznych punktów sprzedaży alkoholu, a nawet godzin sprzedaży tegoż produktu oraz odpowiedzialności za naruszenie tych zakazów. Ważną rolę odgrywają również przepisy związane z tworzeniem aktów planowania na szczeblu województwa lub gminy programów profilaktyki i rozwiązywania problemów alkoholowych. Bezsporne jest więc to, że jednostki samorządu terytorialnego można zaliczyć do podmiotów, którym ustawodawca polecił realizację regulacji przeciwdziałania alkoholizmowi ${ }^{9}$.

W literaturze wskazuje się natomiast, że najszersze uprawnienia w zakresie realizacji zadań dotyczących przeciwdziałania alkoholizmowi spośród wszystkich szczebli samorządu mają właśnie gminy, a w szczególności powoływana obligatoryjnie przez wójta (burmistrza, prezydenta) gminna komisja rozwiązywania problemów alkoholowych ${ }^{10}$.

Jeśli chodzi o uprawnienia jednostek samorządu terytorialnego o charakterze prawnokarnym, to niewątpliwie na pierwszy plan wysuwają się zwłaszcza dwie regulacje, które są bezpośrednio związane z zadaniami, jakie ustawodawca przyznaje gminie.

Po pierwsze, jest to art. $4^{1}$ ust. 1 u.w.t.p.a, w którym wskazano, że prowadzenie działań związanych z profilaktyką i rozwiązywaniem problemów alkoholowych oraz integracji społecznej osób uzależnionych od alkoholu należy do zadań własnych gmin. Wśród tego rodzaju zadań wskazano między innymi uprawnienie wójta do występowania przed sądem w charakterze oskarżyciela publicznego w sprawach o wykroczenia uregulowane we wskazanej ustawie (art. $4^{1}$ ust. 1 pkt 6 u.w.t.p.a.). Zgodnie $\mathrm{z}$ art. $17 \S 3$ kodeksu postępowania w sprawach o wykroczenia organom administracji rządowej i samorządowej, organom kontroli państwowej i kontroli samorządu terytorialnego oraz strażom gminnym (miej-

${ }^{9}$ Por. np. R. Budzisz, B. Jaworska-Dębska, K. Wlaźlak, Rola samorządu terytorialnego $w$ zakresie wychowania $w$ trzeźwości i przeciwdziałania alkoholizmowi (część pierwsza), „Studia Prawno-Ekonomiczne” 79, 2009, s. 53-103; eidem, Rola samorzadu terytorialnego $w$ zakresie wychowania $w$ trzeźwości i przeciwdziatania alkoholizmowi (część druga), „Studia Prawno-Ekonomiczne” 80, 2009, s. 55-87; K. Łukowska, Rozwiqzywanie problemów alkoholowych oraz ograniczanie dostępności alkoholu w gminach i miastach. Przewodnik dla samorzadowców, Warszawa 2018, passim.

${ }^{10}$ M. Koszowski, op. cit., s. 146. 
skim) uprawnienia oskarżyciela publicznego przysługują tylko wówczas, gdy w zakresie swego działania, w tym w trakcie prowadzonych czynności wyjaśniających, ujawniły wykroczenia i wystąpiły z wnioskiem o ukaranie ${ }^{11}$.

Co więcej, straż gminna podlegająca bezpośrednio wójtowi (burmistrzowi, prezydentowi) jest uprawniona do nakładania grzywien w drodze mandatu karnego między innymi za wykroczenia określone w art. $43^{1}$ ust. 1 i 2 oraz art. 45 pkt 2 u.w.t.p.a., a więc czyny, które polegają na nabywaniu lub spożywaniu alkoholu wbrew przepisom oraz na naruszeniu przepisów o dostarczaniu napojów alkoholowych do miejsc sprzedaży lub o uwidocznieniu informacji o szkodliwości spożywania alkoholu ${ }^{12}$.

Drugą ważną instytucją o niewątpliwie prawnokarnym charakterze, której granice są — przynajmniej w jakimś stopniu — określane przez organy gminy jest przestępstwo, o którym mowa w art. 43 ust. 1 i 2 u.w.t.p.a. (tak zwana odpowiedzialność karna sensu stricto). W myśl tego przepisu odpowiedzialności karnej podlega ten, kto sprzedaje lub podaje napoje alkoholowe, gdy jest to zabronione, albo bez wymaganego zezwolenia lub wbrew jego warunkom. Karze podlega także kierownik zakładu handlowego lub gastronomicznego, który nie dopełnia obowiązku nadzoru i przez to dopuszcza do popełnienia w tym zakładzie przestępstwa, o którym mowa w poprzednim zdaniu.

Bezsporne jest to, że zrealizowanie znamion tego przestępstwa jest niejednokrotnie $\mathrm{w}$ dużym stopniu bezpośrednio związane $\mathrm{z}$ tym, $\mathrm{w}$ jaki sposób i w jakim zakresie ze swoich uprawnień skorzystały organy gminy. Decyzja w sprawie wydania albo odmowy względnie pozbawienia, zezwolenia na sprzedaż lub podawanie napojów alkoholowych (tak zwana koncesja) jest bowiem wydawana przez wójta (burmistrza, prezydenta).

Jeśli zaś chodzi o naruszenie zakazu sprzedaży lub podawania alkoholu, to stosowne zakazy są albo wymienione wprost w ustawie, albo też dookreślenie tego rodzaju zakazów pozostawiono w kompetencjach rady gminy, która między innymi ustala, w drodze uchwały, zasady usytuowa-

11 Ustawa z dnia 24 sierpnia 2001 roku - Kodeks postępowania w sprawach o wykroczenia (tekst jedn. Dz.U. z 2019 r. poz. 1120 ze zm.), dalej: k.p.w.

12 Rozporządzenie Ministra Spraw Wewnętrznych i Administracji z dnia 17 listopada 2003 roku w sprawie wykroczeń, za które strażnicy straży gminnych są uprawnieni do nakładania grzywien w drodze mandatu karnego (Dz.U. Nr 208, poz. 2026 ze zm.). 
nia na terenie gminy miejsc sprzedaży i podawania napojów alkoholowych (art. 12 ust. 3 u.w.t.p.a.).

Względnie nowym uprawnieniem rady gminy jest również możliwość ograniczenia między godziną 22:00 a 6:00 dla terenu gminy lub wskazanych jednostek pomocniczych gminy nocnej sprzedaży napojów alkoholowych przeznaczonych do spożycia poza miejscem sprzedaży. Przyznanie gminie tego rodzaju kompetencji rodzi wiele wątpliwości w doktrynie i w orzecznictwie i jest jednym z bardziej spornych zagadnień na płaszczyźnie całej problematyki przeciwdziałania alkoholizmo$\mathrm{wi}^{13}$. Zakaz nocnej sprzedaży alkoholu jest w tym wypadku uregulowany $\mathrm{w}$ akcie prawa miejscowego w postaci uchwały rady gminy. Jego naruszenie zaś - jak wskazuje się w piśmiennictwie — może skutkować odpowiedzialnością karną z art. 43 ust. 1 u.w.t.p.a. ${ }^{14}$

Zaprezentowane regulacje są zagadnieniami, które można bezspornie zaliczyć do problematyki odpowiedzialności karnej, wszak mówimy tutaj o odpowiedzialności przewidzianej w prawie wykroczeń i w prawie karnym w ścisłym tego słowa znaczeniu, a więc rozumianym jako odpowiedzialność karna za przestępstwo.

W tym kontekście pojawia się pytanie, czy represyjny charakter mają tylko te środki reakcji prawnokarnej, które są wprost związane z prawem karnym względnie prawem wykroczeń, czy w grę mogą także wchodzić inne środki reakcji prawnej przewidziane w ustawie o wychowaniu w trzeźwości i przeciwdziałaniu alkoholizmowi.

13 Por. np. J. Wilk, Uchwaty w sprawie ograniczeń w godzinach nocnej sprzedaży napojów alkoholowych przeznaczonych do spożycia poza miejscem sprzedaży. Komentarz praktyczny, Warszawa 2018; A. Misiejko, Nowe przepisy regulujace gminne uchwaty z zakresu wychowania $w$ trzeźwości i przeciwdziałania alkoholizmowi - aspekty wybrane, „Internetowy Kwartalnik Antymonopolowy i Regulacyjny” 2018, nr 4, s. 60-69; B. Przywora, Problematyka ograniczeń $w$ dostępie do napojów alkoholowych na terenie gminy po nowelizacji ustawy o wychowaniu $w$ trzeźwości i przeciwdziałaniu alkoholizmowi z 2018 r. Analiza z perspektywy konstytucyjnej, „Przegląd Prawa Publicznego” 2018, nr 5, s. 45-63; M. Lewicki, Wybrane aspekty kompetencji prawotwórczych gmin $w$ świetle znowelizowanej ustawy o wychowaniu $w$ trzeźwości i przeciwdziałaniu alkoholizmowi, „Samorząd Terytorialny” 2019, nr 4, s. 44 n. Por. też wyrok WSA w Krakowie z dnia 15 stycznia 2019 roku, III SA/Kr 1131/18, LEX nr 2608386.

14 Ograniczenie w nocnej sprzedaży alkoholu na Starym Mieście, komunikat archiwalny z dnia 5 października 2018 roku, www.krakow.pl (dostęp: 31.01.2020).

Nowa Kodyfikacja Prawa Karnego 55, 2020

(C) for this edition by CNS 
W świetle wstępu do niniejszego szkicu i przytoczonych tam poglądów doktryny i orzecznictwa zasadna jest twierdząca odpowiedź na powyższe pytanie. W literaturze wskazuje się bowiem, że przewidziane przez prawo administracyjne środki związane z pozbawieniem pewnych uprawnień są często zbliżone w swym charakterze do kar i środków karnych przewidzianych w kodeksie karnym ${ }^{15}$.

Środki charakteryzujące się — przynajmniej w jakimś stopniu — represyjnym charakterem odnajdujemy także w innych przepisach komentowanej ustawy. Przykładem może być cofnięcie zezwolenia na sprzedaż lub podawanie napojów alkoholowych, które skutkuje niemożnością nie tylko prowadzenia tego rodzaju działalności, lecz także wystąpienia o ponowne wydanie zezwolenia nie wcześniej niż po upływie trzech lat od dnia wydania decyzji o jego cofnięciu (art. 18 ust. 10 i 11 u.w.t.p.a.). Jest to niewątpliwie środek administracyjny, identyczny w skutkach ze środkiem karnym zakazu prowadzenia działalności gospodarczej, który może być orzeczony w razie skazania za przestępstwo popełnione w związku z prowadzeniem takiej działalności, jeżeli dalsze jej prowadzenie zagraża istotnym dobrom chronionym prawem (art. $41 \S 2$ k.k.).

Środkami o charakterze prawnokarnym są zwłaszcza te, które ingerują $\mathrm{w}$ prawa i wolności obywatelskie zagwarantowane w Konstytucji RP, a zwłaszcza związane z krótkotrwałym choćby pozbawieniem wolności lub stosowaniem przymusu. Nie zawsze są one nazywane w taki sposób, jak czyni się to w kodeksie karnym czy też kodeksie postępowania karnego, choć w gruncie rzeczy są podobne do kar czy innych środków przewidzianych w tych kodeksach, a w każdym razie są podobnie odczuwalne, jeśli chodzi o stopień ich represyjności ${ }^{16}$.

Takim środkiem jest niewątpliwie zatrzymanie administracyjne na podstawie art. 40 ust. 1 u.w.t.p.a. w stosunku do osób, które swoim zachowaniem dają powód do zgorszenia w miejscu publicznym lub w zakładzie pracy, znajdują się w okolicznościach zagrażających ich życiu lub zdrowiu albo zagrażają życiu lub zdrowiu innych osób ${ }^{17}$. Wobec

15 A.J. Szwarc, op. cit., s. 14.

16 Ustawa z dnia 6 czerwca 1997 roku - Kodeks postępowania karnego (tekst jedn. Dz.U. z 2020 r. poz. 30), dalej: k.p.k.

${ }^{17}$ Ł. Cora, Zatrzymanie administracyjne na podstawie art. 40 ust. 1 ustawy o wychowaniu $w$ trzeźwości i przeciwdziałaniu alkoholizmowi, „Prokuratura i Prawo” 2008, nr 5, s. 109-119. 
osób, których zachowanie spełnia wskazane w tym przepisie warunki, funkcjonariusze policji, a także straży gminnej mogą zastosować zatrzymanie w celu odprowadzenia ich do izby wytrzeźwień lub innej placówki, względnie podmiotu leczniczego. Gdy nie ma takich palcówek, osoby te mogą być doprowadzone do jednostki policji (art. 40 ust. 2 u.w.t.p.a.).

Osoba doprowadzona do izby wytrzeźwień lub placówki albo jednostki policji przebywa tam aż do wytrzeźwienia, nie dłużej niż 24 godziny. Na doprowadzenie przysługuje zażalenie do sądu rejonowego. W literaturze przedmiotu i orzecznictwie nie jest odosobniony pogląd, że do doprowadzenia osoby nietrzeźwej do izby wytrzeźwień, do sposobu postępowania z nią, a także do zażalenia należy stosować standard właściwy zatrzymaniu w rozumieniu art. 41 ust. 3 Konstytucji $\mathrm{RP}^{18}$. W zażaleniu osoba doprowadzona może domagać się zbadania zasadności i legalności doprowadzenia, jak również decyzji o przyjęciu albo zatrzymaniu oraz prawidłowości ich wykonania (art. 40 ust. 6 zd. 2 u.w.t.p.a.). Identyczność tego rodzaju środka ze środkiem w postaci zatrzymania, o którym mowa w art. 244 k.p.k., nie powinna budzić żadnych wątpliwości, gdy dodamy, że do rozpoznania zażalenia stosuje się właśnie przepisy kodeksu postępowania karnego (art. 40 ust. 7 zd. 2 u.w.t.p.a.).

Innym środkiem reakcji prawnej, niewątpliwie zbliżonym do niektórych środków przewidzianych w prawie karnym, a związanym ze stosowaniem przymusu, jest uprawnienie do podejmowania przez gminną komisję rozwiązywania problemów alkoholowych, zwaną dalej komisją, czynności zmierzających do orzeczenia o zastosowaniu wobec osoby uzależnionej od alkoholu obowiązku poddania się leczeniu w zakładzie lecznictwa odwykowego.

Co prawda ostatecznie o zastosowaniu obowiązku poddania się leczeniu w zakładzie lecznictwa odwykowego orzeka sąd rejonowy właściwy według miejsca zamieszkania lub pobytu osoby, której postępowanie dotyczy, tym niemniej jednak komisja, powoływana przez wójta (burmistrza, prezydenta), jest jednym z dwóch — obok prokuratora -

18 Por. K. Szczucki, Alkoholizm w polskim prawie medycznym, [w:] Szczególne świadczenia zdrowotne. System prawa medycznego, t. 2, red. L. Bosek, A. Wnukiewicz-Kozłowska, Warszawa 2018, s. 569-570. Por. też T. Gardocka, Izby wytrzeźwień - miejsce instytucji w porządku prawnym, [w:] Izby wytrzeźwień a prawa człowieka, red. T. Gardocka, J. Sobczak, Toruń 2013, s. 64-73. 
podmiotów uprawnionych do wszczęcia całej procedury. W następstwie przeprowadzonego postępowania możliwe jest orzeczenie przez sąd obowiązku poddania się leczeniu w zakładzie lecznictwa odwykowego. Środek ten niewątpliwie w swym kształcie jest identyczny jak orzekany w ramach warunkowego umorzenia postępowania karnego, warunkowego zawieszenia wykonania kary, wykonania kary pozbawienia wolności lub warunkowego przedterminowego zwolnienia obowiązek poddania się leczeniu odwykowemu (art. $72 \S 1$ pkt 6 k.k.). Jednakże w literaturze i orzecznictwie podkreśla się, że zupełnie inne są cele orzekania tego środka w postępowaniu karnym niż te, dla których orzeka się go na podstawie art. 26 u.w.t.p.a. ${ }^{19} \mathrm{Z}$ punktu widzenia celów, dla których stosuje się tego rodzaju instytucję, bardziej zbliżone będzie porównanie jej z przewidzianym w kodeksie karnym środkiem zabezpieczającym w postaci terapii, a zwłaszcza terapii uzależnień (art. 93a ust. 1 pkt 2 i 3 k.k.).

\section{Przeciwdziałanie narkomanii}

Innym doniosłym problemem, z którym musi mierzyć się samorząd terytorialny, jest niewątpliwie zjawisko narkomanii ${ }^{20}$. Przeciwdziałanie narkomanii również zostało zaliczone do zadań własnych gminy (art. 10 ust. 1 u.p.n.) W odróżnieniu jednak od zagadnienia przeciwdziałania i zwalczania alkoholizmu kompetencje „karne” gminy odnośnie do zwalczania narkomanii są zdecydowanie mniejsze. Główny nacisk został bowiem położony na działania profilaktyczne, ze szczególnym naciskiem na stworzenie gminnego programu przeciwdziałania narkomanii (art. 10 ust. 2 u.p.n.).

Uprawnienia związane $\mathrm{z}$ realizowaniem państwowego prawa karania zostały przekazane instytucjom państwowym. W ustawie odnajdujemy kilkanaście przestępstw (art. 53-64 u.p.n.) oraz kilka wykroczeń (art. 65-67 u.p.n.), do których ścigania powołane są przede wszystkim prokuratura oraz policja względnie inne służby mundurowe.

19 Postanowienie SN z dnia 9 listopada 2007 roku, V CSK 241/07, LEX nr 361289; K. Szczucki, op. cit., s. 563.

20 Ustawa z dnia 29 lipca 2005 roku o przeciwdziałaniu narkomanii (tekst jedn. Dz.U. z 2019 r. poz. 852 z późn. zm.), dalej: u.p.n. 
Jeśli chodzi o uprawnienia o charakterze prawnokarnym, które ustawodawca przyznał gminie, w zasadzie jedynym środkiem o częściowo represyjnym charakterze jest zagadnienie związane $\mathrm{z}$ nadzorem nad uprawą maku i konopi, które służą do produkcji narkotyków (art. 45-51 u.p.n.). Ustawa reguluje nieliczne prawnie dopuszczalne sytuacje, w których dozwolone jest uprawianie tego rodzaju roślin. W grę mogą wchodzić w szczególności potrzeby przemysłu włókienniczego, chemicznego, celulozowo-papierniczego, spożywczego, kosmetycznego, farmaceutycznego, materiałów budowlanych oraz nasiennictwa (art. 45 u.p.n.).

Decyzje $\mathrm{w}$ przedmiocie udzielenia, odmowy lub cofnięcia tego rodzaju zezwolenia wydaje wójt (burmistrz, prezydent). W wielu wypadkach cofnięcie zezwolenia będzie równoznaczne z zakończeniem prowadzenia działalności gospodarczej (przemysłowej), w której był wykorzystywany mak lub konopie (art. 47 u.p.n.).

Dolegliwość tego rodzaju środka jest potęgowana, jeżeli dodamy, że zgodnie z art. 51 u.p.n. w wypadku stwierdzenia prowadzenia upraw maku lub konopi włóknistych w sposób niezgodny z właściwymi przepisami wójt (burmistrz, prezydent) wydaje nakaz zniszczenia tych upraw przez zaoranie, przekopanie gruntu albo w inny sposób, który zapewni skuteczne wykonanie tego nakazu, na koszt prowadzącego uprawę, a nakazowi nadaje się rygor natychmiastowej wykonalności.

Nakaz zniszczenia tego rodzaju upraw jest w swej istocie zbliżony do znanego prawu karnemu skarbowemu środka karnego w postaci przepadku połączonego ze zniszczeniem w całości lub części przedmiotów podlegających przepadkowi (art. $31 \S 5$ k.k.s.). Identyczne skutki wywołuje orzekany oprócz przepadku środek, który stosuje się za niektóre przestępstwa i wykroczenia uregulowane $\mathrm{w}$ ustawie o przeciwdziałaniu narkomanii (art. 69 ust. 2 u.p.n. oraz art. 70 ust. 2 u.p.n.).

Wyraźnie widać, że - inaczej niż w wypadku przeciwdziałania alkoholizmowi - w sprawach związanych ze zwalczaniem narkomanii ustawodawca ograniczył kompetencje gmin, jeśli chodzi o możliwość egzekwowania odpowiedzialności o charakterze represyjnym. Tymczasem nie powinno budzić żadnych wątpliwości, że problem narkomanii jest niezwykle ważnym zagadnieniem z punktu widzenia funkcjonowania jednostek samorządu terytorialnego. Oczywiste jest przy tym stwierdzenie, że odnośnie do przeciwdziałania narkomanii najskuteczniejszą 
metodą „walki z narkotykami” jest nie tylko represja i stosowanie sankcji, lecz przede wszystkim szeroko rozumiana profilaktyka, zwłaszcza wśród młodzieży. Jak się wydaje, te właśnie względy spowodowały, że ustawodawca uznał, iż najwłaściwszym sposobem realizacji zadań wynikających z państwowego prawa karania będzie przekazanie zdecydowanej większości uprawnień, gdy chodzi o ściganie przestępstw i wykroczeń związanych z narkomanią, powołanym do tego organom ściągania, ograniczając w tym zakresie uprawnienia jednostek samorządu terytorialnego do niezbędnego minimum. Jednocześnie przeciwdziałanie narkomanii zostało uznane za zadanie własne gminy (art. 10 ust. 1 u.p.n.), którego realizacja ma polegać przede wszystkim na profilaktyce, terapii i pomocy, a nie na stosowaniu represji. Nie sposób oczywiście nie zgodzić się z takim założeniem. Niemniej jednak zmieniająca się rzeczywistość oraz wykorzystywany — niejednokrotnie także w złych celach — postęp techniczny spowodował, że w ostatnich kilkunastu latach jednostki samorządu terytorialnego, a zwłaszcza gminy musiały zmierzyć się z nowym zjawiskiem, jakimi niewątpliwie są tak zwane dopalacze.

\section{Przeciwdziałanie tak zwanym dopalaczom}

Odnośnie do genezy tych ,nowych narkotyków” w literaturze dość zgodnie wskazuje się, że pierwsze przypadki sprzedaży przez internet środków narkotycznych niekontrolowanych prawem i będących bezpiecznym substytutem popularnych narkotyków, odnotowano w Nowej Zelandii w latach 1999-2000²1. Od samego początku popularność tego rodzaju środków oraz ich przewaga nad tradycyjnymi narkotykami sprowadzała się do tego, że obrót nimi był — co do zasady — legalny, zwłaszcza w początkowym okresie ich pojawienia się w poszczególnych krajach. Uważano też, że są one bezpieczniejsze od środków narkotycznych, a przy okazji zdecydowanie tańsze ${ }^{22}$. Z tego względu bardzo szyb-

21 D. Błachut, B. Szukalski, Dopalacze - właściwości chemiczne, skala zagrożeń i przeciwdziałanie rozpowszechnianiu, „Przegląd Bezpieczeństwa Wewnętrznego” 2012, nr 6, s. 111.

22 P. Kurowska, Dopalacze - jak walczyć z nowymi truciznami?, „Biuletyn Głównej Biblioteki Lekarskiej” 2018, nr 2, s. 219. 
ko zyskały popularność również w Europie i Stanach Zjednoczonych ${ }^{23}$. Wraz z rosnącą popularnością dostrzegano także niebezpieczeństwo związane z zażywaniem tak zwanych dopalaczy. W związku z tym dość szybko stosowanie tych środków zostało zakazane w wielu krajach Unii Europejskiej, a także w Stanach Zjednoczonych ${ }^{24}$.

W Polsce pierwszy oficjalny sklep z tak zwanymi dopalaczami pojawił się w 2008 roku w Łodzi ${ }^{25}$. W tym samym roku powstała też profesjonalna witryna internetowa (www.doplacze.com) oferująca w legalny sposób nabycie tych środków. To sprawiło, że w Polsce przyjęła się nazwa „dopalacze”, mimo że w światowej literaturze środki te są dość powszechnie określane mianem designer drugs (narkotyki zmodyfikowane ${ }^{26}$. W krótkim czasie handel tymi środkami dotarł do większości polskich miast. Chyba nikt nie kwestionuje szkodliwości tego rodzaju środków. Z punktu widzenia funkcjonowania jednostek samorządu terytorialnego problem był tym większy, że w zasadzie nigdy nie miały one żadnych instrumentów prawnych do zwalczania tego rodzaju negatywnych zjawisk. Wymowne znaczenie w tym względzie ma tytuł jednego z artykułów w gazecie „Rzeczpospolita” z dnia 27 stycznia 2009 roku Miasteczka odurzone najbardziej, w którym wskazywano, jak poważnym problemem dla miast w Polsce są tak zwane dopalacze ${ }^{27}$. W 2010 roku w całej Polsce działało kilkaset sklepów handlujących tymi środkami, a ich liczba stale rosła.

Mimo że kwestia związana $\mathrm{z}$ tak zwanymi dopalaczami oraz negatywnymi dla życia i zdrowia skutkami, z jakimi wiąże się ich zażywanie, była ważnym problemem społecznym, o którym często donosiły media ogólnopolskie, tak naprawdę przez lata to właśnie na gminach (miastach) spoczywał obowiązek walki z tymi substancjami.

23 Por. szerzej C. Wilkins, P. Sweetsur, Differences in harm from legal BZP/TFMPP party pills between North Island and South Island users in New Zealand: A case of effective industry self-regulation, „International Journal of Drug Policy” 21, 2010, s. 86-90.

24 M. Kozubal, Legalne niebezpieczne dopalacze, „,Rzeczpospolita” 23.08.2008.

25 G. Zawadka, W. Wybranowski, Dopalacze schodza do podziemia, ,Rzeczpospolita" 5.10.2010.

26 P. Kurowska, op. cit., s. 219.

27 I.F. Redlińska, Miasteczka odurzone najbardziej, „Rzeczpospolita” 27.01.2009. 
Poszczególne jednostki samorządu terytorialnego podejmowały najróżniejsze działania, które miały utrudnić lub uniemożliwić na ich terenie obrót tak zwanymi dopalaczami. Już w 2010 roku w Warszawie zalecono, aby uniemożliwić sprzedaż tego rodzaju środków w budynkach należących do miasta stołecznego Warszawy i jego poszczególnych dzielnic ${ }^{28}$.

Wiele samorządów próbowało zakazać obrotu tak zwanymi dopalaczami na ich terenie poprzez wprowadzenie odpowiednich przepisów, w których zakazywano obrotu tego rodzaju środkami na terenie danej gminy pod rygorem kary grzywny. Jednakże w większości wypadków uchwały te były uchylane przez organy nadzoru oraz sądy administracyjne. Organy nadzoru i sądy unieważniały ze względu na to, że zagadnienie tak zwanych dopalaczy jest uregulowane w odrębnych ustawach lub innych przepisach powszechnie obowiązujących. Samo uregulowanie sprawy, której dotyczą przepisy porządkowe w odrębnych ustawach czy przepisach powszechnie obowiązujących, jest wystarczającą przesłanką do uniemożliwienia wydania przepisów porządkowych na podstawie art. 40 ust. 3 u.s.g., i to także gdy dane zachowanie nie jest w ogóle obwarowane żadną sankcją - czy to o charakterze administracyjnym, czy też wykroczeniowym ${ }^{29}$.

Wprowadzoną w 2010 roku dość obszerną nowelizacją ustawy o przeciwdziałaniu narkomanii ${ }^{30}$ zakazano handlu tak zwanymi dopalaczami z tym jednak zastrzeżeniem, że za złamanie tego zakazu groziła nie odpowiedzialność karna, lecz jedynie administracyjna kara pieniężna w wysokości od 20 tys. do $1 \mathrm{mln}$ złotych. Organem uprawnionym do wydawania decyzji nakładających tego rodzaju kary ustanowiono Państwową Inspekcję Sanitarną, której przekazano również wiele innych upraw-

28 M. Górecka-Czuryłł, Dopalacze tylko w prywatnych domach, „Rzeczpospolita” 19.07.2010.

29 Por. przykładowo: rozstrzygnięcie nadzorcze Wojewody Warmińsko-Mazurskiego z dnia 16 listopada 2010 roku, PN.0911-240/10, LEX nr 688572; rozstrzygnięcie nadzorcze Wojewody Łódzkiego z dnia 5 sierpnia 2010 roku, PNK.I-0911/302/2010, LEX nr 652110; rozstrzygnięcie nadzorcze Wojewody Dolnośląskiego z dnia 15 lutego 2012 roku, NK-N3.4131.1.2012.DC, LEX nr 1127093; rozstrzygnięcie nadzorcze Wojewody Dolnośląskiego z dnia 6 lipca 2011 roku, NK-N.4131.149.2011.AZ5, LEX nr 963623.

30 Ustawa z dnia 8 października 2010 roku o zmianie ustawy o przeciwdziałaniu narkomanii oraz ustawy o Państwowej Inspekcji Sanitarnej (Dz.U. Nr 213, poz. 1396). 
nień. W założeniu projektodawców noweli miały one ułatwić walkę z tak zwanymi dopalaczami ${ }^{31}$.

Dość szybko okazało się, że tego rodzaju substytuty narkotyków mogą powodować drgawki, mdłości, wymioty, uczucie zagubienia czy psychozy, a także bezsenność. Z każdym kolejny rokiem wzrastała liczba zatruć tymi substancjami, które niejednokrotnie kończyły się śmiercią ich użytkowników. Z przeprowadzonej przez NIK kontroli wynika, że tylko w latach 2010-2016 zgłoszono łącznie 16068 przypadków względnie podejrzeń zatruć tak zwanymi dopalaczami ${ }^{32}$.

Media, najczęściej o zasięgu regionalnym i miejskim, niejednokrotnie informowały o zagrożeniach związanych z tymi środkami i otwieraniem kolejnych sklepów, ostrzegając przed nimi lokalne społeczności ${ }^{33}$. Rosnące zainteresowanie tymi środkami spowodowało, że sklepy handlujące tak zwanymi dopalaczami były masowo otwierane w mniejszych miastach oraz sezonowo w nadmorskich kurortach ${ }^{34}$.

Można przyjąć, że chęć przeciwdziałania tego rodzaju negatywnym konsekwencjom była niewątpliwie jednym z czynników skłaniających poszczególne jednostki samorządu terytorialnego do podjęcia dość radykalnych działań, mających na celu zwalczanie tak zwanych dopalaczy.

W grę oczywiście mogą wchodzić działania oficjalne, jak na przykład zwiększenie liczby patroli służb mundurowych i straży miejskiej $\mathrm{w}$ rejonach handlu dopalaczami ${ }^{35}$. Inną metodą wykorzystywaną przez poszczególne jednostki samorządu terytorialnego jest na przykład utworzenie przy takim sklepie mobilnego posterunku pod dozorem policjanta względnie strażnika miejskiego ${ }^{36}$. W Łodzi miejsce, w którym handlowano dopalaczami, objęto programem modernizacji chodników, pod-

31 Ustawa z dnia 14 marca 1985 roku o Państwowej Inspekcji Sanitarnej (tekst jedn. Dz.U. z 2019 r. poz. 59), dalej: u.p.i.s.

32 Za: https://www.nik.gov.pl/plik/id,17464,vp,20036.pdf (dostęp: 31.01.2020).

33 A. Malczewski, M. Kidawa, Nowe substancje psychoaktywne w Europie. Skala zjawiska i przeciwdziałanie, Warszawa 2018, s. 17.

34 Ibidem, s. 18.

35 Por. Miasto walczy z dopalaczami, https://www.fakt.pl/wydarzenia/polska/poznan/poznan-chce-walczyc-z-dopalaczami-i-zapowiada-wiecej-patroli/q2dq81m (dostęp: 31.01.2020).

36 Por. Tak wojuja z dopalaczami w Pabianicach, https://www.fakt.pl/wydarzenia/ polska/lodz/w-pabianicach-dziala-mobilny-posterunek-policji-i-strazy-miejskiej-ktoregozadaniem/n275cce\#slajd-2 (dostęp: 31.01.2020).

Nowa Kodyfikacja Prawa Karnego 55, 2020

(C) for this edition by CNS 
dając okoliczny obszar renowacji i odgradzając tym samym wejście do lokalu. Przed przekroczeniem zaś barierek określających zasięg prac remontowych przestrzegała groźba mandatu karnego ${ }^{37}$.

Podejmowanie tego rodzaju zabiegów było spowodowane brakiem przepisów, które umożliwiałyby poszczególnym gminom bezpośrednią walkę z opisywanym zjawiskiem. W jednej z wcześniejszych publikacji autor niniejszego opracowania zaproponował wprowadzenie do ustawy o przeciwdziałaniu narkomanii nowego rozdziału, który pozwalałby jednostkom samorządu terytorialnego zwalczanie — jedynie w pewnym zakresie - obrotu tak zwanymi dopalaczami ${ }^{38}$. W szczególności chodzi o sytuacje, gdy sprzedaż tych środków jest prowadzona pod pozorem prowadzenia innej działalności, w tym zwłaszcza gospodarczej (na przykład sprzedaż upominków, materiałów kolekcjonerskich czy tak zwanych podpałek do grilla). Nie zagłębiając się w szczegóły, gdyż nie jest to przedmiotem niniejszego opracowania, można wskazać, że proponowana nowelizacja ma umożliwić jednostkom samorządu terytorialnego bezpośrednią walkę z tak zwanymi dopalaczami ${ }^{39}$. W dużym uproszeniu można powiedzieć, że propozycja ta sprowadza się w zasadzie do

37 Por. Łódź: nowy sposób na walkę z dopalaczami? Wejście do sklepu odcięte przez remont, https:/wiadomosci.gazeta.pl/wiadomosci/1,114871,20171021,lopaty-i-kilofy-przeciwko-dopalaczom-zaskakujacy-pomysl-lodzkich.html (dostęp: 31.01.2020).

38 Gwoli ścisłości należy wskazać, że podstawowe założenia propozycji wprowadzenia przepisów, które mają ułatwiać — w określonym co prawda zakresie — gminom zwalczanie tak zwanych dopalaczy, są wynikiem prac powołanego w Lesznie zespołu, którego zadaniem było przygotowanie stosownych propozycji zmian przepisów prawa. W skład tego zespołu wchodzili między innymi leszczyńscy sędziowie, prokuratorzy i funkcjonariusze policji. Chodzi bowiem o to, aby w ostatecznie stworzyć takie regulacje prawne, które umożliwią skuteczną walkę z obrotem tak zwanymi dopalaczami nie tylko organom ścigania, lecz także samorządowi terytorialnemu. Por. szerzej P. Jóźwiak, Uzasadnienie i propozycja projektu przepisów karnych, majacych na celu zwalczanie obrotu tzw. dopalaczami przez jednostki samorzadu terytorialnego, „Acta Iuris Stetinensis” 2018, nr 2, s. 17-32.

39 Dla pełnej jasności obrazu i klarowności zamieszczonych jedynie skrótowo rozważań zasadne wydaje się przywołanie powyższej propozycji w wymiarze in extenso. Oto proponowane regulacje, mające na celu umożliwienie walki z tak zwanymi dopalaczami wójtom, burmistrzom i prezydentom miast, w których ma miejsce proceder obrotu tymi niebezpiecznymi substancjami. Przede wszystkim należy podkreślić, że proponuje się wprowadzenie do ustawy o przeciwdziałaniu narkomanii rozdziału $6 \mathrm{~b}$ zatytułowanego „Zwalczanie środków zastępczych przez jednostki samorządu terytorialnego”, a w ramach tego rozdziału dodanie następujących przepisów:

Nowa Kodyfikacja Prawa Karnego 55, 2020

(C) for this edition by CNS 
trzech podstawowych kwestii. Po pierwsze - wprowadzenia nowego typu wykroczenia wprowadzającego odpowiedzialność za obrót tak zwanymi dopalaczami w ramach lub pod pozorem prowadzenia działalności gospodarczej, zwłaszcza sugerując jednocześnie inne ich właściwe przeznaczenie. Po drugie - umożliwienia prezydentowi miasta (burmistrzowi, wójtowi) aktywnego udziału w zwalczaniu określonego wycinka procederu związanego z handlem dopalaczami. W szczególności włodarz gminy otrzymałby kompetencje do natychmiastowego zamknięcia punktu, odnośnie do którego istnieje podejrzenie, że prowadzony jest w nim obrót tak zwanymi dopalaczami. Ponadto mógłby występować, jako oskarżyciel publiczny (oczywiście najczęściej przez osoby przez niego do tego upoważnione) przed sądem między innymi w sprawach o opisane wykroczenie. Po trzecie - wprowadzenie nowego typu wykroczenia umożliwiłoby również wykorzystanie do walki z tak zwanymi dopalaczami straży gminnych, które nie mają żadnych uprawnień w tym zakresie, a jak wskazano powyżej niejednokrotnie, czasem nieformalnie mogą być bardzo użyteczne w tej batalii.

„Art. 52b 1. Kto w ramach lub pod pozorem prowadzenia działalności gospodarczej udziela innej osobie środki zastępcze służące do odurzania człowieka, zwłaszcza sugerując jednocześnie inne ich właściwe przeznaczenie,

podlega karze grzywny do 100000 złotych.

2. Usiłowanie, podżeganie i pomocnictwo są karalne.

3. Tej samej karze podlega, kto nie stosuje się do nakazu określonego w art. 52c oraz nakazu określonego w art. 27c pkt 2 ustawy z dnia 14 marca 1985 roku o Państwowej Inspekcji Sanitarnej.

Art. 52c 1. Wójt, burmistrz lub prezydent miasta może wydać postanowienie o nakazaniu powstrzymania się od określonej działalności w razie uzasadnionego podejrzenia, iż sprawca popełnił wykroczenie, o którym mowa w art. 52b.

2. Na postanowienie służy zażalenie do sądu właściwego do rozpoznania sprawy o wykroczenie.

Art. 52d Każdy dowiedziawszy się o popełnieniu wykroczeń, o których mowa w art. 52b, ma społeczny obowiązek zawiadomić o tym Prokuratora lub Policję lub Straż Gminną.

Art. 52e Wójt, burmistrz lub prezydent miasta lub osoby przez nich upoważnione, a w szczególności Straż Gminna, są uprawnieni do występowania w charakterze oskarżyciela publicznego w sprawach o wykroczenia, o których mowa w niniejszym rozdziale.

Art. 52f Orzekanie w sprawach określonych w art. 52 b następuje na podstawie przepisów Kodeksu postępowania w sprawach o wykroczenia”. 
Propozycja ta spotkała się z przychylnym przyjęciem zarówno w doktrynie prawniczej, jak i w piśmiennictwie ${ }^{40}$. Zdecydowano o przedłożeniu tej propozycji Sejmowi RP w formie petycji, w której zaproponowano wprowadzenie do ustawy o przeciwdziałaniu narkomanii przygotowanych rozwiązań ${ }^{41}$.

Warto podkreślić, że bardzo pozytywną opinię o projekcie, który trafił do Sejmu, wyraziło Biuro Analiz Sejmowych. Zdaniem sporządzającego tę opinię P. Bachmata:

Przedstawiona w petycji propozycja nowelizacji ustawy z dnia 29 lipca $2005 \mathrm{r}$. o przeciwdziałaniu narkomanii została przekonująco uzasadniona i co do zasady zasługuje na wsparcie w toku dalszych prac legislacyjnych przed Sejmem. Należy przy tym wyeksponować fakt, iż kształt złożonej propozycji normatywnej jest skutkiem prac koncepcyjnych o doniosłym ciężarze merytorycznym, zainicjowanych przez samorząd miasta Leszna [...]. W perspektywie aksjologicznej petycja dotyczy doniosłej społecznie kwestii zapewnienia skutecznych rozwiązań prawnych służących walce z zagrożeniami dla życia i zdrowia zwłaszcza osób młodych, jakie wynikają z faktu dostępu do tzw. dopalaczy, wprowadzanych na rynek niejednokrotnie w sposób skrywający ich faktyczne przeznaczenie $^{42}$.

Równie pozytywnie do projektu podeszła Komisja Petycji Sejmu RP, która po raz pierwszy chyba w swej historii postanowiła jednogłośnie, wnieść do Sejmu projekt ustawy w całości i w kształcie zaproponowanym przez wnioskodawcę, to jest miasto Leszno. Przedstawiająca na posiedzeniu Komisji petycję poseł Kornelia Wróblewska stwierdziła, że ,[w]rażenie zrobiło na mnie to, że zanim projekt trafił do parlamentu, wykonano nad nim wielomiesięczną pracę" ${ }^{\text {"43. }}$

40 Ł. Pohl, Uwagi w związu z przygotowanym przez władze miasta Leszna projektem przepisów karnych majacych na celu zwalczanie obrotu tak zwanymi dopalaczami, „Acta Iuris Stetinensis” 2018, nr 2, s. 5-16; W. Farfecki, Sejmowy cios w dopalacze, „Rzeczpospolita” 20.08.2019.

41 W. Farfecki, Leszno wie jak pokonać dopalacze, „Rzeczpospolita” 16.04.2019.

42 P. Bachamt, Opinia prawna na temat petycji BKSP-145-509/19 w sprawie nowelizacji ustawy z dnia 29 lipca 2005 r. o przeciwdziałaniu narkomanii, http://orka.sejm. gov.pl/petycje.nsf/nazwa/509/\$file/509.pdf (dostęp: 31.01.2020).

43 W. Ferfecki, Sejmowy cios... 


\section{Podsumowanie}

Zaprezentowane w niniejszym opracowaniu — jedynie na zasadzie reprezentatywnego przykładu — negatywne zjawiska (alkoholizm, narkotyki i tak zwane dopalacze) znajdujące się w zakresie właściwości poszczególnych gmin są niewątpliwie ważnymi problemami, z którymi muszą mierzyć się jednostki samorządu terytorialnego.

Przyznany samorządom przez ustawodawcę zakres uprawnień do przeciwdziałania tego rodzaju zjawiskom jest różny. Począwszy od dość szerokich kompetencji, gdy chodzi o przeciwdziałanie alkoholizmowi, poprzez niewielki zakres uprawnień związanych z przeciwdziałaniem narkomanii, a skończywszy na braku de lege lata uprawnień, gdy chodzi o zwalczanie dopalaczy.

Przywołana propozycja wprowadzenia de lege ferenda do ustawy o przeciwdziałaniu narkomanii przepisów umożliwiających poszczególnym gminom zwalczanie tak zwanych dopalaczy za pomocą przepisów o charakterze prawnokarnym pokazuje, że czasem mogą być to niezwykle potrzebne regulacje, których celem jest nie tylko represja, lecz także — a być może przede wszystkim — prewencja. Realizacja tych celów powinna następować $\mathrm{w}$ ramach wykonywania przez gminy zadań własnych — zaspokajania zbiorowych potrzeb wspólnoty w zakresie porządku publicznego i bezpieczeństwa obywateli (art. 7 ust. 1 pkt 15 u.s.g.).

Jak wskazano, stosowanie przepisów o charakterze prawnokarnym nie jest podstawowym zadaniem gmin, lecz warto czasem z nich korzystać, zwłaszcza gdy w grę wchodzi ochrona życia i zdrowia mieszkańców.

\section{Bibliografia}

Bachamt P., Opinia prawna na temat petycji BKSP-145-509/19 w sprawie nowelizacji ustawy z dnia 29 lipca 2005 r. o przeciwdziałaniu narkomanii, Warszawa 2019, http://orka.sejm.gov.pl/petycje.nsf/nazwa/509/\$file/509.pdf (dostęp: 31.01.2020).

Błachut D., Szukalski B., Dopalacze - właściwości chemiczne, skala zagrożén i przeciwdziałanie rozpowszechnianiu, „Przegląd Bezpieczeństwa Wewnętrznego” 2012, nr 6.

Budzisz R., Jaworska-Dębska B., Wlaźlak K., Rola samorządu terytorialnego w zakresie wychowania w trzeźwości i przeciwdziałania alkoholizmowi (część pierwsza), „Studia Prawno-Ekonomiczne" 79, 2009. 
Budzisz R., Jaworska-Dębska B., Wlaźlak K., Rola samorządu terytorialnego w zakresie wychowania $w$ trzé́wości i przeciwdziałania alkoholizmowi (część druga), „Studia Prawno-Ekonomiczne" 80, 2009.

Cora Ł., Zatrzymanie administracyjne na podstawie art. 40 ust. 1 ustawy o wychowaniu w trzeźwości i przeciwdziałaniu alkoholizmowi, „Prokuratura i Prawo” 2008, nr 5.

Farfecki W., Leszno wie jak pokonać dopalacze, „Rzeczpospolita” 16.04.2019.

Farfecki W., Sejmowy cios w dopalacze, „Rzeczpospolita” 20.08.2019.

Gardocka T., Izby wytrzeźwień - miejsce instytucji w porzadku prawnym, [w:] Izby wytrzeźwień a prawa człowieka, red. T. Gardocka, J. Sobczak, Toruń 2013.

Górecka-Czuryło M., Dopalacze tylko w prywatnych domach, „Rzeczpospolita” 19.07.2010.

Jóźwiak P., Represyjne kompetencje wójta (burmistrza, prezydenta) w świetle zasady in dubio pro cive, [w:] Represyjność prawa samorzadowego, red. A.J. Szwarc, T. Gardocka, Poznań 2015.

Jóźwiak P., Uzasadnienie i propozycja projektu przepisów karnych, mających na celu zwalczanie obrotu tzw. dopalaczami przez jednostki samorzadu terytorialnego, „Acta Iuris Stetinensis” 2018, nr 2.

Kasiński M., Ekspansja represyjnej funkcji administracji publicznej jako zagrożenie demokratycznego państwa prawnego, „Roczniki Nauk Prawnych” 21, 2011, nr 1.

Koszowski M., Przeciwdziałanie uzależnieniom. Regulacje prawne, Warszawa 2019.

Kozubal M., Legalne niebezpieczne dopalacze, ,Rzeczpospolita” 23.08.2008.

Królikowski M., Zawłocki R., Prawo karne, Warszawa 2015.

Kurowska P., Dopalacze - jak walczyć z nowymi truciznami?, „Biuletyn Głównej Biblioteki Lekarskiej” 2018, nr 2.

Lewicki M., Wybrane aspekty kompetencji prawotwórczych gmin w świetle znowelizowanej ustawy o wychowaniu w trzeźwości i przeciwdziałaniu alkoholizmowi, ,Samorząd Terytorialny" 2019, nr 4.

Łukowska K., Rozwiązywanie problemów alkoholowych oraz ograniczanie dostęności alkoholu w gminach i miastach. Przewodnik dla samorządowców, Warszawa 2018.

Malczewski A., Kidawa M., Nowe substancje psychoaktywne w Europie. Skala zjawiska i przeciwdziałanie, Warszawa 2018.

Misiejko A., Nowe przepisy regulujace gminne uchwaty z zakresu wychowania $w$ trzeźwości i przeciwdziałania alkoholizmowi - aspekty wybrane, „Internetowy Kwartalnik Antymonopolowy i Regulacyjny" 2018, nr 4.

Pohl Ł., Uwagi w zwiazku z przygotowanym przez władze miasta Leszna projektem przepisów karnych mających na celu zwalczanie obrotu tak zwanymi dopalaczami, „Acta Iuris Stetinensis” 2018, nr 2.

Przywora B., Problematyka ograniczeń $w$ dostepie do napojów alkoholowych na terenie gminy po nowelizacji ustawy o wychowaniu $w$ trzeźwości i przeciwdziałaniu alkoholizmowi z 2018 r. Analiza z perspektywy konstytucyjnej, „Przegląd Prawa Publicznego" 2018, nr 5.

Redlińska I.F., Miasteczka odurzone najbardziej, „Rzeczpospolita” 27.01.2009. 
Staniszewska L., Administracyjne kary pieniężne. Studium z zakresu prawa administracyjnego i procesowego, Poznań 2017.

Szczucki K., Alkoholizm w polskim prawie medycznym, [w:] Szczególne świadczenia zdrowotne. System prawa medycznego, t. 2, red. L. Bosek, A. Wnukiewicz-Kozłowska, Warszawa 2018.

Szumiło-Kulczycka D., Prawo administracyjno-karne, Kraków 2004.

Szwarc A.J., Niektóre aspekty represyjności prawa samorząowego, [w:] Represyjność prawa samorzadowego, red. A.J. Szwarc, T. Gardocka, Poznań 2015.

Wilk J., Uchwaty w sprawie ograniczeń w godzinach nocnej sprzedaży napojów alkoholowych przeznaczonych do spożycia poza miejscem sprzedaży. Komentarz praktyczny, Warszawa 2018.

Wilkins C., Sweetsur P., Differences in harm from legal BZP/TFMPP party pills between North Island and South Island users in new Zealand: A case of effective industry self-regulation, „International Journal of Drug Policy” 21, 2010.

Zawadka G., Wybranowski W., Dopalacze schodza do podziemia, „Rzeczpospolita” 5.10.2010.

Zoll A., Wróbel W., Polskie prawo karne. Część ogólna, Kraków 2010.

\section{Some legal repressive methods of drug and alcoholism prevention, including particularly designer drugs, by municipalities}

\section{Summary}

The role of territorial self-government in alcoholism and drug control is significant. Municipalities have the widest competence in this sphere. Among the many different rights granted to municipalities, one can distinguish those of a prophylactic, preventive, but also criminal (repressive) nature. The latter are the subject of this article. The role of territorial self-government is not - as a rule - the use of repressive measures, but sometimes they are extremely effective in fighting against such negative phenomena as alcoholism or drug addiction. That is why the article proposes introducing solutions of a criminal nature, which are to help municipalities fight against designer drugs.

Keywords: alcoholism, drug, designer drugs, repressive nature. 